\title{
Resolving Jurisdiction Conflicts between Courts and Arbitral Tribunals: A Chinese Law Perspective
}

\author{
Xiaohong Liu*
}

The question of conflict of jurisdictions between courts and arbitral tribunals not merely constitutes a purely theoretical issue, but it also has significance in the legal practice. When many countries show allowance to arbitration and support its development to the greatest extent, few courts in China fail to tackle the relationships between arbitration and courts. By means of an analysis of possible conflict of the jur isdictions between courts and arbitral tribunals, this article pleas for a supportive attitude of courts with respect to arbitration, so as to reduce the impact of courts' judicial supervision on the due arbitration proceeding. In-depth theoretical discussions will develop on the principle of "competence-competence" and its application in China, justifying the conclusion that the essence of this principle is to have disputes between parties in arbitration agreements solved within the arbitration system and thereby to respect the parties' decision to submit to arbitration.

\section{Introduction}

The question of conflict of jurisdictions 1 between courts and arbitral tribunals not merely constitutes a purely theoretical issue, but it also has significance in the legal practice of these institutions.

A heavily debated topic in the literature on international arbitration is that referring to the distribution of power between courts and arbitrators in order to determine the

* Ph.D. Professor of law at East China University of Political Science \& Law, Shanghai, Arbitrator of China International Economic and Trade Arbitration Commission and Shanghai Arbitration Commission, Mediator of Shanghai-Rhone-Alps International Mediation Center.

1 In this paper the words "jurisdiction," "power" and "competence" will be used interchangeably, with the understanding that the distinction between them made in some legal systems essentially fades away at the international level. 
validity, and the personal and subject matter scope of an arbitration clause. ${ }^{2}$ The traditional attitude of judges towards arbitration has been one of considerable hostility. The reason for this lies not only in the fact that an arbitration agreement may "oust" court jurisdiction over parties' commercial disputes, but also in that there is concern over the withdrawal from the court system of cases in which public values are involved, or fear that arbitral institutions might ignore or undermine the enforcement of laws. Moreover, courts' revenues may be at stake if the number of arbitrations increases. ${ }^{3}$ Hence, even in some developed countries in which arbitration has developed and flourished for a considerable time, judicial skepticism towards arbitration often prevails. So, the relationship between arbitration and litigation is not merely a legal problem. Rather, it is a social problem arising from more varied considerations. Gradually, along with the steady development of international commercial arbitration, the attitude of most legal authorities towards arbitration seems to have evolved from hostility, to tolerance and gradually even to support. The principle of "competence-competence" in favor of arbitral institutions is becoming increasingly accepted. 4

However, although law institutions in many countries nowadays promote arbitration and support its development, a few courts in China still fail to accept a mutually beneficial relationship between themselves and arbitral institutions within their jurisdiction. The main reason is that the increase in the number of arbitrations results in a partial loss of jurisdiction for courts and tends to entail a negative impact on courts' generation of income. Some courts maintain an outdated negative perception of arbitration, and even tend to disapprove of its existence. Some courts also unduly overemphasize the importance of their supervisory function with respect to arbitration, and sometimes even abuse their supervisory competence. In addition, some courts tend to deal with arbitral awards merely at the level of their preliminary judgements and therewith interfere unduly with the arbitration process, as if they were called upon to pass judgement in an appeals trial. This way, judicial authority may constitute an obstacle for a smooth arbitration process, which runs counter to the interests of parties which have themselves opted for arbitration. The Revpower Case, 5 for instance, is one illustrative example of a case in which a court put up judicial obstacles aimed at frustrating arbitration. In such cases, because conflicts of jurisdiction between Chinese

2 Christian Herrera Petrus, Spanish Perspectives on the Doctrines of Kompetenz-Kompetenz and Separability: A Comparative Analysis of Spain's 1988 Arbitration Act., 11 Am. Rev. InT'L ARB. 397 (2000).

3 John Murray, Alan Scott RaU \& Edward Sherman, Processes of Dispute Resolution, The Role of LAWYERS 435 (The Foundation Press 1992).

4 See generally Peter Gross QC, Competence of Competence: An English View, 8 ARB.INT'L 2 205, 214 (1992), Antonias Dimolitsa, Separability and Kompetenz-Kompetenz, ICCA CONGRESS SERIEs No. 9 217, 256 (1999), Kompetenz-Kompetenz, ICCA Congress Series No. 9 217, 256 (1999).

5 The case will be invoked and discussed in the IV part of this paper. 
courts and commercial arbitration institutions are not yet dealt with in a proper way, the positive image of Chinese courts and even China's reputation as a loyal commercial partner in the international economic and legal community are at stake. 6

This paper embodies five parts. By reference to relevant theory and practice in some developed countries, in-depth theoretical discussions will develop on the principle of "competence-competence," justifying the conclusion that the essence of this principle, is to have disputes between parties in arbitration agreements solved within the arbitration system and thereby to respect the parties' decision to submit to arbitration. Furthermore, through the analysis on possible conflict of jurisdiction between courts and the arbitral tribunals, the present author pleas for a supportive attitude on the side of courts with respect to arbitration, so as to restrain the impact of courts' judicial supervision on the due arbitration procedures. Finally, this article investigates the position and role of the "competence-competence" principle in legislation and practice of the Chinese arbitration system, and submits some recommendations pertaining thereto.

\section{The Types of Jurisdictional Conflicts Between Courrs and Arbitral Tribunals}

\section{A. Conflicts between Arbitral Tribunals and Courts at the Place of Arbitration}

1. Determining Arbitral Jurisdiction by Arbitration Institutions: Application of the "Competence-Competence" Principle

Jurisdiction with respect to international commercial arbitration refers to the legal competence possessed by an arbitration tribunal or other arbitral institution to engage in the trial of an international commercial dispute and to the institution's ability to carry through arbitral proceedings. ${ }^{7}$ Nowadays, it is universally accepted that jurisdiction with respect to arbitration is a principal, albeit preliminary, issue in international commercial arbitration. Obtaining arbitral jurisdiction with respect to commercial

6 See generally Randall Peerenboom, Seek Truth From Facts: An Empirical Study of Enforcement of Arbitral Awards in the PRC, 49 AM. J. COMP. L. 249 (2001).

7 See generally Russell Weintraub, International Litigation and Arbitration (Carolina Academic Press 2nd ed. 1997). 
disputes constitutes the legal basis for the start of arbitral proceedings, and fulfills one of the preconditions for a lawful arbitral award and its enforcement. The competence of arbitral institutions in most cases arises from an arbitration clause incorporated into a commercial agreement concluded between disputing parties. According to several theories and legislations relating to international commercial arbitration, it is generally agreed that the conclusion of an arbitration agreement normally is the primary precondition for the commencement and proceeding of an arbitral process. Thus, the entire jurisdiction of an arbitral tribunal is limited to the disputes submitted to it by parties by reference to a mutual agreement. 8 This is commonly referred to as jurisdiction arising from an arbitration agreement. ${ }^{9}$ Parties confer upon the arbitral tribunal, and the authority to hear disputes and thereafter to perform its duties within the limits of such authorization.

The meaning of jurisdiction with respect to international commercial arbitration is comprised of two elements: one refers to the general legal authority enjoyed by arbitral institutions to seize and hear cases in dispute; the other relates to the determination of a jurisdiction with respect to a specific point of dispute. Though arbitration is a private and voluntary dispute resolution process that invests in private individuals the authority to hear a dispute, while simultaneously divesting courts of such authority, 10 it might happen that an arbitral tribunal, when beginning to exercise its jurisdiction on the basis of an arbitration agreement entered into by parties of a dispute, encounters a partial challenge or total challenge raised by parties against its arbitral jurisdiction. Partial jurisdictional challenge mainly involves the assertion that the arbitral tribunal exceeds its jurisdiction 11 , and does not respect its jurisdictional limits imposed by the arbitration agreement. However, in most circumstances involving total challenge, the validity of the arbitration agreement is at stake. In the practice of international commercial arbitration, an arbitration agreement may include various flaws or defects, or even be invalid or unenforceable for various reasons. Moreover, even in the case of a valid arbitration agreement, parties may take contradictory positions and opinions due to their different interpretation of relevant agreement provisions, laws and arbitration practices. Parties even may challenge the validity of an arbitration agreement with the objective being only to prolong or frustrate the arbitration process. It has turned out that in a substantial number of arbitration cases, controversies with respect to the validity of

10 Janet Rosen: Arbitration Under Private International Law: The Doctrines of Separability and Competence de la Competence, 17 FordHAM INT'L L.J. 599 (1994).

11 Here refer to some issues are beyond the scope of arbitration agreement concluded by both parties. 
an arbitration agreement and arbitral jurisdiction arising from it are raised to challenge the legal validity of the arbitration process as such. Thus, some $15 \%$ of the cases accepted by the China International Economic and Trade Arbitration Commission (CIETAC) in recent years involve challenges to arbitral jurisdiction. 12 In the event that a party raises a total challenge against the arbitral tribunal's jurisdiction, it is necessary to first rule on the validity of the arbitration agreement. Only after arbitral jurisdiction has been established, can the entire arbitration process make progress with full deference to the parties' apparent intentions and correct interpretation of its provisions, as expressed in the agreement. Otherwise, parties may request for competent courts to set aside or refuse to enforce the arbitral award because of a lack of arbitral jurisdiction subsequent to the issuance of an arbitral award, which would result for both parties in a tremendous waste of time, energy and money.

In the event that a party raises a total challenge against an arbitral tribunal's jurisdiction, which authority should rule on such a challenge? A relevant competent court, the arbitral tribunal involved, or another arbitration institution? In other words, is an arbitral tribunal invested with the competence to decide upon its own jurisdiction? At present, such power has been confirmed by both legislation and practice in the field of international commercial arbitration. In the past, it was traditionally held that in the case of a dispute over an arbitral tribunal's jurisdiction, it should be determined by a competent court.13 However, modern theory and practice also recognize the arbitral tribunal's concurrent competence to rule itself on jurisdictional challenges raised by any of the parties. This theory is based upon the so-called "competence-competence" principl (or "Kompetenz/Kompetenz" in German). 14 This theory originated in Germany, 15 and has now developed into a basic theory in the field of international commercial arbitration. 16

The theory of "competence-competence" supplies a proper theoretical basis for arbitral institutions to determine their own jurisdiction. 17 This doctrine provides that arbitral tribunals are invested with the competence to be judges of their own jurisdiction .18 Thus, the essence of this theory is that an arbitral tribunal may rule its own

12 Wang Shengchang, Arbitration jurisdiction Determination System with Chinese Characteristics, 5 ARBitRATION AND LAW (2003).

13 Zhao Jian, Judicial Supervision in International Commercial Arbitration 89 (Law Press 2000).

14 A. Redfern \& M. Hunter, LaW and Practice of International Commercial Arbitration 213 (3rd ed.1999).

15 Christian Herrera Petrus, Spanish Perspectives on the Doctrines of Kompetenz-Kompetenz and Separability: A Comparative Analysis of Spain's 1988 Arbitration Act., 11 AM. Rev. INT'L ARB. 397(2000).

16 See generally Robert Smit, Separability and Competence-Competence in International Arbitration: Ex Nihilo Nihil Fit? Or Can Something Indeed Come from Nothing? 13 AM. REv. INT'L ARB. 19 (2002).

17 Mahir Jalili, Kompetenz-Kompetenz: Recent U.S. and U.K. Developments, 13 J.INT’L ARB. 169-178 (1996).

18 Rosen, Supra note 11. 
jurisdiction with respect to a specific arbitration agreement, including its validity; and that its jurisdiction does not depend anymore on a prior judicial ruling. As this theory deals with the question of how to resolve the issue of "the competence to determine competence," it is called the principle of "competence-competence"19 In essence, the core of this theory is based on how to allocate jurisdiction over the interpretation and enforcement of arbitration agreements between courts and arbitral institutions. 20

Under the principle of "competence-competence," arbitrators may determine the existence of the arbitration clause, its validity and its scope 21 and parties shall not invoke the jurisdiction of a national court to determine these issues.22 The principle of "competence-competence" has been justified on two grounds: first, there is a nonrebuttable presumption that such jurisdictional power has been conferred by the will of the parties when they entered into their arbitration agreement; and second, this competence is inherent to the capacity of all judicial bodies and essential to their ability to function.23 One further very practical important reason for recognition of the "competence-competence" principle lies in the fact that if one party could deprive an arbitral tribunal of the competence to rule upon the validity of a contract, then it would always be possible for a party to make an agreement containing an arbitration clause to vitiate its arbitral obligation by declaring the agreement void.

The "competence-competence" principle somehow looks like a theoretical paradox: an arbitral tribunal's jurisdiction derives from a valid arbitration agreement concluded by parties; however, when any of these parties contests the validity of an arbitration agreement, i.e., challenges the arbitral tribunal's jurisdiction, it is the arbitral tribunal which is endowed with the legal capacity to rule on the validity of an arbitration agreement. Scholars have submitted various theories attempting to seek a theoretical foundation for the "competence-competence" principle. Some conceive that it was derived from the mutual consent of parties, some others believe its roots lie in domestic legislation or convention, i.e. pre-arbitration legal sources, while again others conceive it as to have stemmed from the concept of allocation of interests. 24 At present, it has become generally accepted that an arbitral tribunal's authority to decide on its own

19 Supra note 14.

20 Redfern \& Hunter, supra note 14, Steven Walt, Decision by Division: the Contractarian Structure of Commercial Arbitration, 51 RuTGERs L. REv. 369-370 (1999).

21 Alan Redfern, the Jurisdiction of an International Commercial Arbitrator, 3 J. INT'L ARB. 19, 30 (1986).

22 Janet Rosen, Arbitration Under Private International Law: The Doctrines of Separability and Competence de la Competence, 17 FordHAM INT'L L.J. 599 (1994).

23 Ibrahim F.I. Shihata, The Power of the International Court to Determine Its JuRisdiction 25-26 (1965).

24 Feng Kefei, The Theory of Competence-Competence and Its Practice in China, 1 ARBITRATION AND LAW 101 (2002). 
jurisdiction arises from the arbitration agreement entered into by both parties. The fact that both parties have agreed to submit disputes to arbitration, reflects their intention to allow disputes arising between them to be settled by arbitration instead of by a court. Unless otherwise agreed, the authority to pass judgment on the merits of disputes under an arbitration agreement has been allocated to the arbitral tribunal in question. Thus, the competence of an arbitral tribunal to decide its own jurisdiction mainly arises from the authorization given by the parties especially, of course, when parties have expressly authorized the arbitral tribunal to determine its own jurisdiction. ${ }^{25}$ Such authority enjoyed by an arbitral tribunal is absolutely necessary for an effective performance of its tasks and assignments. Accordingly, scholars today tend to agree that both in arbitral and the judicial proceedings, tribunals shall be the judges of their own jurisdiction. ${ }^{26}$ It is the arbitral tribunal's inherent competence to determine its own jurisdiction; "indeed, it is an essential power if the arbitral tribunal is to carry out its task properly." 27

The "competence-competence" principle has in the meantime been generally recognized in international conventions on international commercial arbitration and in many national arbitration legislations, as a fundamental principle of international commercial arbitration law; for instance, it was recognized in the 1961 European Convention on International Commercial Arbitration,28 the European Uniform Law on Arbitration,29 and Convention on the Settlement of Investment Disputes between States and Nationals. 30 Indeed, art. 16 (1) of the UNCITRAL Model Law stipulates that "the arbitral tribunal may rule on its own jurisdiction, including any objections with respect to the existence or validity of the arbitration agreement."31 Similar provisions can also be found in domestic legislations. ${ }^{32}$ In addition, the arbitration rules of some well-known permanent international arbitration institutions also contain similar provisions, such as art.15 of the 1997 American Arbitration Association (AAA) International Arbitration Rules, art.23 of the 1998 Arbitration Rules of the London Court of International Arbitration, and art.21 of the UNCITRAL Arbitration Rules.33 Since the

25 Zhao, supra note 13 , at 96.

26 Andrew Rogers QC \& Rachel Launders: Separability-the Indestructible Arbitration Clause, 10 ARB. INT'L, 79 (1994).

27 Redfern \& Hunter, supra note 14, at 264.

281961 European Convention on International Commercial Arbitration art. 5.

29 European Uniform Law on Arbitration art. 18.

30 Convention on the Settlement of Investment Disputes between States and Nationals art. 41.

31 UNCITRAL Model Law art. 16(1).

32 See e.g. art. 1466 of French Civil Procedure Code, art. 86 of Switzerland's Federal Code on Private International Law, art. 1040 of German Civil Procedure Code, art. 1052 (1) of Holland Civil Procedure Code, and art. 23 (3) of Spanish Arbitration Law, etc.

33 Other countries, including Belgium, Holland and Switzerland have accepted this doctrine. See Carlos E. Alfaro \& Flavia Guinarey, Who Should Determine Arbitrability? Arbitration in a Changing Economic and Political Environment, ARB. INT'L (1996). See also Ning Min, Song Lianbin, Jurisdictional Principles in 
"competence-competence" principle has been recognized in the legislation and legal practice of many countries, arbitral awards rendered by arbitral tribunals which have determined their own jurisdiction have to be recognized by competent courts.

When discussing the "competence-competence" principle, there is still another issue worthy of further exploration: namely whether the subject of this theory only applies to arbitral tribunals or also to other arbitration institutions. This issue does not arise in the case of ad hoc arbitration, since an ad hoc arbitral tribunal is an ad hoc arbitration institution. But in the case of institutionalized arbitration, arbitration institutions and arbitral tribunals represent two different concepts, having different functions and assignments. The principal task of a permanent arbitration institution is to administer the daily operation of the arbitration mechanism governed by it. An arbitration institution does not participate in the hearing of cases, but can make a preliminary ruling on the validity of an arbitration agreement under consideration, in terms of the prima facie evidence of whether parties have indeed entered into an arbitration agreement, thereby deciding on whether a specific arbitration case should or should not be accepted. It is the arbitral tribunal's function to hear a specific case and finally render an award. ${ }^{34}$ The true meaning of the "competence-competence" theory is to let arbitrators decide on their own jurisdiction. In most international commercial arbitration cases, arbitrators play a leading role in the determination of arbitral jurisdiction. Indeed, it can be noticed that the laws of some countries and arbitration rules of several arbitration institutions confer the authority on arbitration institutions to ascertain the validity of arbitration agreements and to decide on arbitral jurisdiction. 35 In any case, in the present author's opinion, relatively uniform recognition exists in the field of international commercial arbitration, that the essence of the "competencecompetence" theory shall be strictly respected, and that the role of arbitration institutions in determining arbitral jurisdiction shall be considered as restricted, while the role of

International Commercial Arbitration, 2 LAW REvIEW (2000). However, it should be mentioned that there is a controversy among U.S. arbitration circles as to whether there is a "competence de la competence doctrine" in the U.S. Some U.S. scholars hold the view the "competence de la competence doctrine" not espoused under U.S. case law and pursuant to Article 4 of FAA. Rosen, Supra note 18.

34 For example, as stipulated in Article 6 (Effect of Arbitration Agreement) of Rule of arbitration of the International Chamber of Commence of 1998: If any party raises one or more pleas concerning the existence validity or scope of the arbitration agreement, the Court may decide, without prejudice to the admissibility or merits of the plea or pleas, that the arbitration shall proceed if it is prima facie satisfied that an arbitration agreement under the Rule may exist. In Such a case, any decision as to the jurisdiction of the Arbitral Tribunal shall be taken by the Arbitral Tribunal itself. If the Court is not so satisfied, the parties shall be notified that the arbitration cannot proceed. In such a case, any party retains the right to ask any court having jurisdiction whether or not there is a binding arbitration agreement.

35 Such as the Arbitration Law of the PRC, Arbitration Rules of the Arbitration Institute of the Stockholm Chamber of Commerce. 
arbitrators (arbitral tribunals), in terms of determining their own competence shall be further emphasized.

\section{Supervisory Competence of Courts: Judicial Supervision over Arbitration Procedures}

The principle of jurisdiction with respect to arbitration agreements and the "competence-competence" principle constitutes the legal basis for arbitral tribunals to exercise jurisdiction. However, by reference to states' legislations and arbitration rules, the "competence-competence" principle establishes the arbitral tribunals' competence to decide on jurisdictional challenges raised by parties during the early stages of an arbitration process. This principle does not imply that arbitrational jurisdiction shall be determined by the arbitral tribunal under all circumstances. Moreover, a jurisdictional decision made by an arbitral tribunal is not final, but is subject to judicial examination. In theory, the final determinative authority of a court to rule on the validity of an arbitration agreement derives from judicial supervision over arbitration. Moderate judicial supervision over arbitration (including judicial support and supervision) has been generally accepted in the arbitration circle either from the perspective of the contractual nature of arbitration, the realization of the values of arbitration, or the legitimate tasks of courts. ${ }^{36}$ The arbitral tribunal shall conduct arbitration on the basis of arbitration agreements in terms of provisions of law and its basic principles, like those of equity and good faith. The conduct of arbitration and the final arbitral award affect not only the interests of parties but also the equity of the whole society. Courts exercising jurisdiction on behalf of the state are responsible for maintaining social justice and safeguarding the unity of the state's legal system. In addition, judicial support is necessary for conducting arbitral proceedings or realizing the values of the arbitration system. Judicial supervision over arbitration is quite necessary, and the authority of courts to determine the validity of arbitration agreements is accepted as one of the matters allowing judicial interference both in theory and in practice. Some scholars call this theory "determinism of the court", in terms of which courts are invested with authority to determine the validity of arbitration agreements and arbitral tribunals' jurisdiction. 37

36 Zhao, supra note 13, at 15-18.

37 Zhao Xiuwen, Research on International Commercial Arbitration and the Applicable LaW 43 (Peking University Press 2002). 
"Court supremacy" has been recognized in many countries' arbitration legislations and arbitration rules of some international arbitration institutions. For instance, the UNCITRAL Model Law stipulates, "if the arbitral tribunal rules as a preliminary question that it has jurisdiction, any party may request, within 30 days after having received notice of that ruling, the court specified in the article 6 to decide the matter of which decision shall be subject to no appeal; while such a request is pending, the arbitral tribunal may continue the arbitral proceedings and make an award."38 German Civil Procedure Law provides: "In respect of objections to jurisdiction, the arbitral tribunal ordinarily may render an interlocutory award if it considers that it has jurisdiction. In this circumstance, either party may request, within one month after receiving the award, the court to decide the matter. The arbitral tribunal may continue the arbitral proceedings and make an award."39 Likewise, the Swiss Inter-cantonal Concordat on Arbitration (1969) stipulates, "parties dissatisfied with the preliminary award on jurisdiction may appeal to the local court and request the court to make a final determination."

Compared with the authority of an arbitral tribunal to determine its own jurisdiction and the validity of arbitration agreements at stake in cases submitted to it, the jurisdiction of a court with respect to arbitration agreements is broader. A court may examine jurisdictional decisions taken by an arbitral tribunal at the following three stages:

Stage 1

When arbitration proceedings are initiated, parties may directly challenge the jurisdiction of arbitration tribunals before a court. Thus, while one party initiates arbitral proceedings, the other party may challenge the arbitral tribunal's jurisdiction before the court and refuse to attend arbitration. Under such circumstances, usually the court of the place of arbitration has authority to decide on the legal relevance of objections raised by parties against an arbitral jurisdiction.

\section{Stage 2}

During arbitral proceedings, parties may challenge the jurisdiction of arbitration before the arbitral tribunals directly, in which case the arbitral tribunal in question may render an interim award to confirm or reject its jurisdiction. An interim award rendered by an arbitral tribunal is subject to control of a court. The party dissatisfied with an interim award may request a local court to rule on such matter. Some states' legislations provide that the party dissatisfied with the interim award rendered by the arbitral tribunal may promptly lodge a complaint with a local court and 
request the latter to make a final decision. 40

\section{Stage 3}

Parties in arbitral proceedings may request a court at the place of arbitration to set aside the arbitral award in question on the ground that the arbitral tribunal lacks jurisdiction. The competent court may exercise judicial review over such an arbitral award by reference to provisions of the agreement in question. If the court finds that the arbitration agreement is invalid, the court may set aside the arbitral award rendered on the basis of such an agreement.

The "competence-competence" principle authorizes arbitral tribunals to decide on their own jurisdiction, but arbitrators are not the sole decision-makers. Rulings made by arbitral tribunals on the validity of arbitration agreements and their own jurisdiction with respect to them are ultimately subject to the supervision and control of competent courts. Courts may "interfere in" 41 arbitration proceedings at different stages, which may give rise to competence conflicts between courts and arbitral tribunals with respect to arbitral jurisdiction. When arbitral proceedings are initiated or in process of such proceedings, the "competence-competence" principle conflicts directly with relevant courts' authority to determine the validity of arbitration agreements. Identical conflicts may arise again in an indirect way after an arbitral award has been rendered when subsequently a competent court decides to set aside such an award by determining that the arbitral tribunal did not have jurisdiction.

It shows that although arbitral jurisdiction overrides judicial jurisdiction by reference to an arbitration agreement, the final authority to determine the jurisdiction of an arbitration tribunal still rests upon courts. Conflict of jurisdiction thus may arise between courts and arbitral tribunals. A fundamental reason for such a conflict is caused by the fact that, though arbitral tribunals are entitled to render interim or final awards that are binding for parties by reference to the "competence-competence" principle, courts can overrule arbitral jurisdiction decisions and refuse to recognize and enforce arbitral awards. Therefore, it can be concluded that national arbitration laws do not result in conferring ultimate authority of interpretation and enforcement upon arbitral tribunals when the validity of arbitration agreements and their jurisdiction are at stake. Ultimate judgment on the legal merits of arbitral awards, as well as their recognition and enforcement, rely on judicial supervision and support, which explains the potential

40 See Swiss Inter-cantonal Concordat on Arbitration (1969) arts. 9 \& 36(2).

41 The word "interference" as used here by this author is neutral. UNCITRAL has ever pointed out expressly in a document that the meaning of the word "interference" contained in art. 5 of the Model Law also covers assistance of courts. See Howard Holzmann \& Josph NeuHaus, A Guide to the UNCITRAL Model LaW on INTERNATIONAL COMMERCIAL ARBITRATION: Legislative History AND COMMENTARY 216 (Kluwer 1994). 
existence of conflict of jurisdiction between courts and arbitral tribunals. Thus, the solution for this kind of jurisdictional conflict between the arbitral tribunal and courts will ultimately be subject to the court supremacy.

\section{B. Conflicts between Arbitral Tribunal and the Court out of the Place of Arbitration}

Arbitral tribunal's competence to determine the validity of an arbitration agreement may not only conflict with the concurrent competence of courts at the place of arbitration exercising judicial supervision, but may also conflict with the possible competence of courts elsewhere in the event that one party to the arbitration agreement disregards the existence of the agreement and directly submits a case to a court at a different location, asserting that the relevant agreement is invalid. Another possible problem may arise if one party goes to court while the other party, alleging the valid existence of the disputed arbitration agreement requests a court to terminate litigation proceedings and to refer the dispute to arbitration. 42 In this case, the court in question has to decide on the validity of the arbitration agreement. Scholars call such determination of jurisdiction, which is made during a litigation process, a preliminary ruling on arbitral jurisdiction. 43 In addition, courts at the place where enforcement of an arbitral award is sought also have concurrent authority to refuse enforcement when they conclude that the arbitral tribunal in question lacks jurisdiction; which is expressly stipulated in Article 5 of 1958 New York Convention. Furthermore, the issue of which law is applicable to a particular arbitration case may be encountered when arbitral tribunals or courts have to decide on the validity of relevant arbitration agreements, i.e. whether the arbitration law of the place of forum shall be applied to determine the validity of the arbitration agreement in question. This issue may further complicate the solution to a conflict relating to competence.

In fact, the above-mentioned conflict relates to situations in which parallel jurisdiction between an arbitral tribunal and a court exists. Under this circumstance, a domestic court cannot exercise its supremacy over a decision made by a foreign arbitral tribunal with regard to the validity of an arbitration agreement. This kind of conflict cannot be easily settled and is subject to application of relevant conventions or treaties concluded at multilateral and bilateral levels.

42 This situation may well be illustrated by the Revpower case at Weintraub, see supra note 7.

43 See Adam Samuel, Jurisdictional Problems in International Commercial Arbitration: A Study of Belgian,Dutch, English, French, Swedish, Swiss, U.S, and West German LaW 186-187 (Schulthess Polygraphischer Verlag 1989). 


\section{Solving the Jurisdiction Conflict between Courts and Arbitral Tribunals}

\section{A. Principle of Concurrent Competence}

Taking into account present international commercial arbitration theories and legislations, many countries have adopted a legal system relating to concurrent competence of courts and arbitral tribunals. Under such a system, arbitral tribunals are authorized to make a preliminary ruling on their own arbitral jurisdiction by reference to the principle of "competence-competence". Parties challenging such a preliminary ruling may lodge a complaint with a local court (the court at the place of arbitration) and request that this court render a final decision. A decision of the court on the validity of the arbitration agreement that conflicts with the preliminary ruling of the arbitral tribunal is decisive.A decision of the court on the validity of the arbitration agreement that conflicts with the preliminary ruling of the arbitral tribunal is decisive.The merit of this control system lies in the fact that concurrent jurisdiction conflicts can be settled at a comparatively early stage.This enables parties to know their legal positions as soon as possible, and to avoid wasting money and time. However, some scholars oppose this system on the following grounds:

\footnotetext{
Firstly, arbitration shall be conducted free from external "interference" whenever possible, and resorting to courts shall not be encouraged during arbitral proceedings; otherwise the effectiveness and attractiveness of the instrument of arbitration will be imperiled.

Secondly, resorting to court during arbitral proceedings, if permitted, might be utilized as a strategy by parties reluctant to submit to, or wishing to delay or block arbitral proceedings.
}

As a result, consistent with the current trend towards weakening judicial interference prevailing all over the world, not all national legal systems empower courts to make rulings on the issue of jurisdiction during an arbitration process. Many countries take the view that legislation would stimulate courts to decrease their competence to interfere with arbitral proceedings and that supervision over arbitration should only be exercised after an arbitral award has been rendered, if necessary at all. This already is the case in, e.g. France, Italy, Holland, and Belgium. 44

44 See art. 1458 of the 1981 French Civil Procedure Code, arts. 816, 819 of the 1994 Italian Civil Procedure Code, art. 1052 of the Dutch Civil Procedure Code, and art. 1697 of 1985 Belgian Judicial Law Code. 


\section{B. Three Approaches}

The concurrent control system was conceived of as an effective means to determine whether an arbitral tribunal has jurisdiction, and to settle conflicts of jurisdiction between courts and arbitral tribunals. 45 However, at present a universally adopted method still does not exist as regards the detailed operation of this concurrent control system. In this respect domestic laws still adopt different approaches, which reflect the varied attitude of judicial system towards arbitration: 46

The first approach is that parties can bring the issue of arbitral jurisdiction to courts as an independent issue during an arbitral procedure. This approach has been adopted in, e.g. the United States, Sweden, and Sri Lanka;

The second approach is that arbitral tribunals may decide on objections raised against their jurisdiction, and that courts may interfere or exercise supervision only after an award has been rendered. According to this approach, courts' interference in arbitral proceedings may only occur when parties are dissatisfied with the jurisdictional decision made by the arbitral tribunal in question. In this case, a court will render a definite ruling on the preliminary decision taken by an arbitral tribunal. This is the proper "concurrent control" system, which is adopted by, e.g. Switzerland.

The third approach is that arbitral tribunals are entitled to decide their own jurisdiction while the scope of possible objections to their self-declared jurisdiction is broad, This not only relates to the valid existence of an arbitration agreement and the scope of the arbitration clause embodied therein, but also to the composition of the arbitral tribunal. Parties may, of course, extend or limit the scope of arbitrational jurisdiction according to their liking. This unique approach has been adopted in the UK Arbitration Act of 1996.

In addition, the UNCITRAL Model Law on International Commercial Arbitration (hereinafter referred to as "the Model Law") has finally adopted the system of concurrent control, despite fervent discussions during the course of the drafting process. 47 The Model Law did not follow the approach of Holland, which initially was adopted in its first draft; notably that, jurisdictional decisions made by arbitral tribunals shall never be subject to judicial interference during the process of arbitration, unless a valid argument can be raised. Thus, any objection against such decision made by arbitral tribunals can only be raised after an arbitral award has been rendered. The

\footnotetext{
45 Alan Redfern, The Jurisdiction of an International Commercial Arbitrator, 3 J. INT'L ARB. 19, 30 (1986).

46 Ning Min, Song Lianbin, Jurisdictional Principles in International Commercial Arbitration, 2 LAW REvIEW (2000). See also Antonias Dimolitsa, Separability and Kompetenz-Kompetenz, 9 ICCA Congress Series 217 256 (1999).

47 Supra note 41.
} 
Model Law does not follow the approach of the second draft either, i.e. that arbitral tribunals and courts enjoy concurrent jurisdiction with respect to objections to jurisdiction, while arbitral tribunals, in case an objection is raised within a court, can decide to suspend their proceedings. But if an arbitral tribunal confirms its jurisdiction, judicial examination shall not take place until the arbitral award is challenged. The Model Law conciliates such bifurcation on the basis of the approach adopted by Switzerland, which is embodied in art.16 (3): "A court can decide whether the dispute is to be referred to arbitration upon the request of the respondent during a litigation process prior to arbitral proceedings." However, neither party shall go to court with an application that the court shall determine the validity of arbitral jurisdiction in dispute. Once the arbitral proceeding has been initiated, the court shall not order suspension of the arbitral proceedings. Judicial examination of jurisdictional decisions made by arbitral tribunals may be exercised only when the award is challenged. The arbitral tribunal in question may choose to enter a preliminary ruling to make judicial examination promptly available. The time period allowed for parties to file an application with a court is restricted in order to limit the time involved by judicial examination, and the arbitral tribunal can decide to continue the arbitral proceedings without suspension. 48 The compromise formula of the Model Law has been proven to be successful. By reference to the tremendous influence the Model Law has exerted on international commercial arbitration, 49 the system of concurrent control embodied in art.16 will certainly continue to have a significant impact on the settlement of jurisdiction conflicts between courts and arbitral tribunals.

\section{Legislative Framework for Arbitral Jurisdiction in China}

As regards the domestic arbitration in which both parties are Chinese citizens, there is no doubt that the entire arbitration proceeding should follow the domestic arbitration procedure law, which includes the PRC's Arbitration Law and Civil Procedure Law promulgated in 1995 and 1991 respectively. However, the importance of some of the functions of national laws has been somewhat reduced through the promulgation and ratification of international treaties, such as the New York Convention on the Recognition and Enforcement of Foreign Arbitral Awards, June 10, 1958 ("The New 48 Id.

49 Corpus on International Commercial Arbitration, translated and edited by Arbitration Research Institute of China Chamber of International Commerce (China Foreign Economic and Trade Press 1998). 
York Convention of 1958")50, and other relevant international commercial law. The New York Convention of 1958 is an international treaty that obliges member countries to enforce foreign arbitral awards except in certain limited circumstances in which the validity of the award may be called into question. While in case of arbitration with foreign involvements, the application of the international law or a foreign arbitration law might be taken into consideration. Thus, the legal framework of arbitration in China is at both domestic and international level.

\section{A. Arbitral Jurisdiction Based on Arbitration Agreement}

Prior to the implementation of the PRC's Arbitration Law, Civil Procedure Law of China did not deal with questions concerning the determination of validity of arbitration agreements. Though the Arbitration Law, which was enacted in 1995, does not fully recognize arbitral tribunals' authority to decide on the validity of arbitration agreements and their jurisdiction with respect to them, Article 5 and Article 20 of the Arbitration Law, and Article 257 of the Civil Procedure Law do establish arbitrations tribunals' primary jurisdiction with respect to disputes arising under arbitration agreements. In the first place, Article 5 of the Arbitration Law provides that when litigants have concluded an arbitration agreement and one litigant starts a suit before a People's Court, this Court shall not accept and hear the case. However, this prohibition does not apply when the court concludes that the arbitration agreement in question is invalid. Thus, an arbitration institution's primary jurisdiction arising from an arbitration agreement is recognized, and confirmed in other laws and regulations. For instance, Article 305 of a document called Several Opinions on the Application of the Law of Civil Procedure of the People's Republic of China, which was issued by the Supreme People's Court, provides that "according to Article 34 and Article 246 of the Law of Civil Procedure of the PRC, with respect to cases falling within the scope of the People's Court's exclusive jurisdiction, litigants shall not agree in writing to place the case under the jurisdiction of a foreign court. However, exception is to be made when an arbitration agreement has been concluded." It shows that arbitrational jurisdiction is not subject to courts' superior jurisdiction. Even with respect to disputes falling within the scope of courts' exclusive jurisdiction,51 if parties have chosen via mutual agreement to submit their disputes to arbitration, arbitrational jurisdiction still takes precedence over

51 Such exclusive jurisdiction is provided, for example by art. 246 of Civil Procedure Law of P.R.China as: "Civil actions arising from disputes over the implementation of contracts of Chinese foreign joint venture, Chineseforeign cooperative enterprises and Chinese-foreign joint exploration and exploitation of natural resources are 
court jurisdiction. This provision, to some extent, reflects a supportive attitude towards arbitration in China.

\section{B. Application of the Competence-Competence Principle in China}

Chinese law has recognized the "competence-competence" principle in favor of arbitral tribunals at both the international and domestic levels. China signed and ratified the Convention on The Settlement Of Investment Disputes Between States And Nationals Of Other States in 1992, Article 41 of which stipulates "The Tribunal shall be the judge of its own competence" ... "Any objection by a party to the dispute that that dispute is not within the jurisdiction of the Center, or for other reasons does not fall within the competence of the Tribunal, shall be considered by the Tribunal which shall determine whether to deal with it as a preliminary question or to deal with it within the framework of the merits of the dispute." Obviously, this Article confers upon the Tribunal a full right to decide on its jurisdiction, and confirms that China has recognized the "competence-competence" principle in favor of arbitral tribunals at the level of international law.

With respect to domestic legislation, the first part of Article 20 of the Arbitration Law provides "Where a litigant takes exception to the validity of the arbitration agreement, he may request that the arbitration commission take a decision or that the people's court pass judgment." It is clear that this article first confers upon the arbitration institution a concurrent competence to decide on the validity of arbitration agreements.

\section{Court Supremacy}

The second part of Article 20 of the Arbitration Law provides that "where one litigant requests that the arbitration commission take a decision while the other litigant requests the People's Court to pass judgment, the People's Court shall pass such judgment". In addition to this provision, a document called Reply to Several Problems on the Affirmation of the Validity of Arbitration Agreements, issued by the Supreme People's Court on October 21, 1998,52 further explains the division of competence between arbitral tribunals and courts to affirm the validity of an arbitration agreement: Firstly, when a litigant takes exception to the validity of an arbitration agreement and requests the arbitration commission to confirm the validity thereof, whereas the other litigant

under the jurisdiction of the people's court of the PRC."

52 See Judicial Interpretation No.27 of 1998, enacted by "The Judicial Communiqué" of the Supreme Court of 
requests a People's Court to deny its validity, and in the event that the arbitration commission has already positively decided on its validity before the People's Court deals with the matter, the Court shall not seize the case; while in the event that the arbitration commission has not taken a decision before the court, the Court shall seize and hear the case and instruct the arbitration commission to terminate its arbitration procedure. In addition, if one litigant refers contractual disputes or disputes over property rights to arbitration while the other litigant, challenging the validity of arbitration agreement, requests a People's Court to deny the validity of this arbitration agreement and to pass judgment on such disputes, the People's Court, after accepting and hearing the case, shall order the arbitration commission to suspend arbitration. A copy of the judgment passed by the People's Court affirming or rejecting the validity of arbitration agreement shall be submitted to the arbitration commission, which then shall resume or cancel its arbitration proceedings in accordance with the judgment. If a People's Court rejects the validity of the arbitration agreement while the other litigant refuses to appear before the court, the court may proclaim a verdict by default. If an arbitration commission which has initially accepted an application for arbitration fails to dismiss the case after the validity of arbitration agreement has been rejected by the People's Court, this does not affect the legally binding force of the People's Court's judgment.53 Arbitration rules of PRC institutions in charge of arbitration, such as the Rules of Arbitration of the China International Economic and Trade Arbitration Commission, and the Rules of Arbitration of the China Maritime Arbitration Association, embody provisions similar to Article 20 of the PRC's Arbitration Law.54

\section{Comments on Some Disputed Issues}

The above-mentioned laws reveal the core features of China's current arbitration jurisdiction system. In comparison with the prevailing implementation of the "competence-competence" principle in favor of arbitral institutions in many other countries, its unique characteristics lie predominantly in the following aspects: Firstly, courts can interfere with arbitral proceedings prior to their beginning, and exercise superior authority over arbitral tribunals' jurisdiction. Secondly, the Chinese implementation of the "competence- competence" principle does not cover the

the People's Republic of China, which was enforced on November 5, 1998.

53 Jingzhou Tao, Arbitration Law and Practice in China 56-59, 69-70 (2004).

54 Article 4 of the Rules of Arbitration of the China International Economic and Trade Arbitration Commission (2000); Article 4 of the Rules of Arbitration of the China International Economic and Trade Arbitration 
authority of arbitral tribunals, but only that of other arbitral institutions. Scholars' views and comments on this phenomenon are both positive and negative. 55 Some issues arising from this system even have provoked acute controversies in both domestic and international arbitration circles.

\section{Is the Judicial Supervision of the People's Court over the Jurisdiction of Arbitral Tribunals Legally Appropriate?}

Some commentators take the view that Chinese courts have exercised excessive judicial supervision over arbitral tribunals' jurisdiction. Some scholars point out that, although the principle of "competence-competence" in commercial arbitration has been recognized by China at the international level, China still has not recognized it completely at the domestic level. By reference to Article 20 of the Arbitration Law and relevant interpretations adopted by the Supreme People's Court, People's Courts are entitled to take precedence over arbitral tribunals in dealing with disputes arising over arbitrational jurisdiction. This has provoked rather excessive interference by courts with arbitration procedures and has restricted the competence of arbitral tribunals. 56 Indeed, under current circumstances arbitration is subject to judiciary supremacy. To confer upon People's Courts preferential jurisdiction on disputes over arbitral institutions' jurisdiction undoubtedly amounts to denial of the very principle of "competencecompetence" in favor of arbitration. 57 However, other scholars have pointed out that in legal practice, judicial interpretations relating to arbitrational jurisdiction issued by the Supreme People's Court subsequent to the implementation of the Arbitration Law reveal a certain tendency towards a more "pro-arbitration" oriented attitude. 58

The present author believes that, although the Arbitration Law and other relevant laws confer upon courts, the ultimate authority to rule on the (in)validity of arbitration agreements, the principle of "competence-competence" in favor of arbitral institutions is therewith not denied ipso facto. After all, Article 20 of the Arbitration Law recognizes arbitration commissions' authority to decide on the validity of arbitral agreements; also,

Commission (2001).

55 Zhang Yulin: Towards the UNCITRAL Model Law- A Chinese Perspective, 1 J. INT. ARB. 109 (1994), MARC Blessing, The Arbitration Agreement (High-lights on Critical Issues in LaW and Practice, Corpus on InTERnAtional Commercial Arbitration) 101-109 (China Foreign \& Trade Press 1998), Zhao, supra note 13, at 101-109, Wang Shengchang, Arbitration Jurisdiction Determination System with Chinese Characteristics, 5 ARbitration AND LaW 14 (2003).

56 See Zhao, supra note 13, at 101-109. Feng Kefei, The Theory of Competence-Competence and Its Practice in China, 1 Arbitration AND LaW 103 (2002).

57 Xie Shisong (ed.), Commercial Arbitration Law 209-210 (High Education Press 2003).

58 Wang Shengchang, Arbitration Jurisdiction Determination System with Chinese Characteristics, 5 ARBITRATION AND LAW 14 (2003). 
the internationally prevailing "concurrent control" system has also been adopted in the Chinese system to resolve potential competence conflicts with respect to the determination of the (in)validity of arbitration agreements, even if courts ultimately enjoy preferential jurisdiction. Thus, it can be concluded on good grounds that the legislative guidelines on this issue in China emphasize and maintain the People's Courts' power to decide on arbitrational jurisdiction. And in order to ensure a correct exercise of authority by People's Courts, the Supreme People's Court issued its Notice on Several Issues for the People's Courts to Handle Foreign-related Arbitration and Foreign Arbitration, hereinafter referred to as Notice on August 29, 1995. This system provides that in foreign-related arbitrations, where a lower court determines that an arbitration agreement is invalid, it must report such decision to the Higher People's Court for approval. If the decision is upheld by the higher court, such decision must be referred for an approval to the Supreme People's Court. This rather unique system of appeal also applies where a court, pursuant to an application, refuses to enforce foreignrelated arbitration awards. 59 It is clear that this Pro-reporting system entails a strict and substantially multi-level review and bears influence upon the arbitration jurisdiction judgment, passed by People's Courts. Under this system, a supervisory mechanism is established entailing top-down supervision over the judicial performance of lower courts with respect to the question of (in)validity of arbitration agreements. Its purpose is to prevent lower courts from denying the validity of arbitration agreements arbitrarily and by vesting ultimate authority in the Supreme People's Court. Many scholars recognize the positive assets of this unique system and consider it an effective mechanism conducive to constraining the nation-wide tendency of lower local courts claiming competence with respect to arbitrational jurisdiction questions, at the expense of arbitration institutions. 60

As far as Chinese legislation on courts' judicial supervision over arbitral tribunals' jurisdiction improvement is concerned, the following aspects should primarily be considered:

Firstly, Chinese courts currently tend to interfere with arbitral proceedings

The Notice of the Supreme People's Court Regarding the Handling by the People's Court of Certain Issues Relating to Foreign-Related Arbitration and Foreign Arbitration on August 29, 1995 provides the following viz.:... where, pursuant to a suit brought by a party, a court determines that an arbitration agreement involving foreign elements is invalid, ceases to be valid or that its contents are unclear and unenforceable, then prior to rendering such decision, the court shall report its determination to the High People's Court in its own area of jurisdiction for the purpose of examination, and, if the High People's Court in its own area of jurisdiction for the purpose of examination, and, if the High People's Court agrees with the determination of the lower court, it shall report its examination opinion to the Supreme People's Court. No Determination to the application may be rendered pending a reply from the Supreme People's Court." 
prematurely, while such premature interference tends to result in stagnate of arbitral proceedings. As is the case with "concurrent control" systems adopted by some other countries, interference from courts should preferably be exercised only after the implementation of the "competence-competence" principle by arbitral institutions. However, according to the judicial interpretations issued by the Supreme People's Court, courts may acquire the right to decide on arbitrational jurisdiction prior to arbitral tribunals under many circumstances. Moreover, unless arbitration institutions have exercised their jurisdiction over a case before courts have dealt with cases under consideration and have taken decisions on them, once courts are examining the validity of an arbitration agreement, arbitration institutions shall suspend their proceedings until courts have passed final judgment. 61 As a result, litigants at times tend to abuse the possibility of court procedures to avoid or at least delay arbitration. However, recent judicial interpretation of Chinese law on arbitration has shown a tendency to favor the jurisdiction of arbitration commission, e.g. according to "The Judicial Interpretation of Supreme Court of P.R. China on Certain Issues of the Application to the 'Arbitration Law of P.R. China'", the People's Court should not accept and hear a case, if none of the parties concerned has challenged the validity of an arbitration agreement before the first arbitration hearing, but has submited a request to the People's Court for a decision.62 Certain restraining mechanisms adopted by some other countries can be taken as a frame of reference; such as the prescription that, although courts have the right to examine and take decisions on the jurisdiction of arbitration institutions, arbitral proceedings do not have to be suspended automatically during court proceedings. 63

Secondly, some stipulations addressing the allocation of authority to determine the validity of arbitration agreement between courts and arbitral tribunals are too obscure. Article 20 of the Arbitration Law only provides that when both an arbitration commission and a court are entitled to decide on the validity of an arbitration agreement, and the decisions of the arbitration commission and the court turn out to be incompatible, the court's ruling will prevail. However, the law is silent on whether a decision made by an arbitration commission on the validity of an arbitration agreement can be final; in other words, whether courts can exercise judicial supervision when the revocation of an arbitral award is at stake, or when the recognition and enforcement of an arbitral award is the subject of a dispute. Indeed, different interpretations have developed both in theory and in practice on this issue. Some hold the view that

61 John ShiJan Mo, Arbitration LaW In ChINA 104-110 (2001).

62 Article 13 of The Judicial Interpretation of Supreme Court of P.R. China on certain issues of application to the "Arbitration Law of P.R. China" (to be enforced as from Sept. 8, 2006 ).

63 British Arbitration Law art. 67(2); German Code of Civil Procedure art. 1040(3). 
decisions made by arbitration institutions on jurisdiction are final, 64 whereas the majority, including the present author, takes the view that such decisions are not final and subject to judicial supervision. The crucial idea behind recognition of the principle of competence de la competence is to establish arbitral institutions' authority to decide on their jurisdiction, so as to prevent litigants from willfully delaying arbitral proceedings. However, this does not automatically imply that such authority, if vested in arbitral institutions, can be exempt from judicial supervision. It should be pointed out clearly that the law does not provide that rulings issued by People's Courts on the validity of arbitration agreements can be submitted for appeal to higher court; therefore, in this sense such rulings are final. But awards made by arbitral commissions are not final. Participants can still submit applications to courts to confirm or deny the validity of such awards by initiating litigation proceedings in order to seek the revocation of an arbitral award or to prohibit its enforcement. As observed above, the original idea behind the "competence-competence" principle is to empower arbitral tribunals to determine their jurisdiction themselves and prevent litigants from willfully delaying arbitration proceedings, but this does not imply that this authority of arbitral tribunals can be exempt from the scope of judicial supervision. Chief justice Xiao Yang of the Supreme People's Court of China, during an interview conducted by Ms. Gao Fei, chief editor of "China Arbitration", pointed out that "relevant laws do not provide that judgments passed by People's Courts affirming the validity of arbitration agreements are subject to appeal, and that such judgments are final in this sense. However, decisions made by arbitration commissions are not final and litigants can request courts to review the validity of an arbitration agreement when applying for revocation or prohibition of enforcement of an arbitral award." 65

Thirdly, if an arbitration institution finds that an arbitration agreement is invalid, which results in a denial of the arbitral tribunal's jurisdiction, the People's Court, under current Chinese legislation, will have no chance to review the negative decision reached by the arbitration institution. As judicial review can only be conducted during litigation proceedings aimed at revocation or prohibition to enforce an arbitral award, awards with respect to enforcement can only be made in cases where the decisions of the arbitration institution in question are confirmative. Obviously, when we look into courts' judicial supervision responsibility from the perspective of ensuring and realizing litigants' intent to freely choose the dispute settlement method of their liking, it should be observed that current Chinese legislation still seem to tend more towards protecting parties opting for litigation than parties opting for arbitration.

64 The Legal Committee of the Standing Committee of the National People's Congress, Interpretattons and Comments on ARBitration Law of PRC 43 (Law Press 1997).

65 Gao Fei, Support and Supervision of Chinese Courts Toward Arbitration, 6 China ARBitration 7 (2001). 


\section{Is Competence-Competence Principle Really Implemented in China?}

As the Chinese Arbitration Law confers upon arbitration commissions, instead of arbitral tribunals, and the right to decide the validity of an arbitration agreement, some scholars take the view that the Chinese system is unique in allowing arbitral commissions to decide their own jurisdiction. This approach is quite different from the one adopted by prominent international arbitration institutions, such as the International Court of Arbitration of the International Chamber of Commerce. Article 6(2) of its Arbitration Rules provides that if any party raises one or more pleas concerning the existence, validity or scope of an arbitration agreement, the International Court may decide that the arbitration shall proceed if it is satisfied prima facie that an arbitration agreement under the Rules exists. In such case, any decision as to the jurisdiction of an Arbitral Tribunal shall be taken by the Tribunal itself. If the Court is not satisfied, the parties shall be notified that the arbitration cannot proceed. In such a case, any party retains the right to ask any court endowed with jurisdiction whether or not a binding arbitration agreement exists, notwithstanding the original decision made by the Court. Accordingly, some scholars have pointed out that the "competencecompetence" principle in favor of arbitral institutions in China has not yet really been implemented; there still only exists a rather rudimentary or "paternalistic" form of implementation of the "competence-competence" principle.66

As mentioned above, this Chinese "competence-competence" system with its unique characteristics is widely criticized by Chinese theorists and members of law practicing circles. 67 The main points are the following: Firstly, this approach is contrary to the original idea behind the "competence-competence" principle and is incompatible with jurisprudence on international commercial arbitration. Moreover, this approach is not consistent with general international practice concerning the principle of "competencecompetence". The fact that arbitration institutions, which do not deal with specific cases, take the place of arbitral tribunals to deal with jurisdictional challenges not only shows a tendency towards administrative interference, but also results in undue dependence of arbitral tribunals on arbitration institutions; consequently, they both lack legally desirable independence. Thus, the impartiality of arbitral tribunals is then influenced negatively. Moreover, under this approach, the assignment of arbitral tribunals is to take decisions and to render awards on substantive legal issues, whereas arbitral commissions are responsible for determining arbitral tribunals' jurisdiction. The result 
of this artificial division is that substantive hearing and jurisdiction issues are handled by different organs and persons, which contributes to potential incompatibility of the jurisdictional decisions, especially when jurisdictional disputes and substantive disputes cannot be completely separated. Even more important is the consideration that if a jurisdictional decision has to be made by an arbitration institution, arbitration proceedings have to be interrupted, which is at the expense of desirable flexibility and efficiency. 68

At the same time, in the view of commentators who support the Chinese "competence-competence" system, this system enriches implementation of the principle of "competence-competence" and has successfully contributed to settling a great deal of arbitration jurisdiction cases in practice. 69 Some scholars also have pointed out that the most significant function of the "competence-competence" principle lies in allocating concurrent jurisdictional authority between courts and arbitration commissions. In this sense, its purpose can also be realized by leaving jurisdictional issues to be decided by arbitral institutions. In addition, in this respect the jurisdiction of arbitral institutions is identical with that of arbitral tribunals. The intention of arbitration agreements is to submit specific disputes, when they arise, to a specific arbitral institution. Only when an arbitration agreement is validly concluded and disputes submitted fall within the scope of its arbitration clause, can the arbitration institution be entitled to seize and hear the relevant case and the arbitral tribunal entitled to deal with substantive issues. The essence of the principle of "competence-competence" is to enable arbitral institutions to decide on their own jurisdiction. 70

Moreover, under China's current arbitration legislation framework, the mechanism through which arbitration institutions are endowed with the competence to determine their arbitration jurisdiction is advisable. In theory, it is not inconsistent with the jurisdictional nature and autonomy of judgment that decisions on arbitrational jurisdiction are left up to the arbitration institutions themselves. The competence of arbitration institutions is partly derived from the parties' autonomy to choose rules of arbitration commissions, and partly from the allocation of authority as provided for in legislation. Most importantly, from the perspective of legal practice, the method by

68 Relevant comments can be found in Ning Min, Song Lianbin, Jurisdictional Principles in International Commercial Arbitration, 2 LAW Review (2000); Zhao, supra note 15, at 100-109, Kang Ming, Ad Hoc Arbitration and Its Current Situation and Development in China, 3 ARBitration AND LaW (2000), Qiao Xin, Research on the Right of Arbitration 191 (2001), Xie Shisong(ED.), Commercial Arbitration Law 212213(2003), Song Lianbin, Research on Jurisdiction in International Commercial Arbitration 94-95 (2000), Zhang Binsheng, New Research on Arbitration Law 170-171 (2002), Zhang Yulin: Towards the UNCITRAL Model Law-A Chinese Perspective, 1 J. InT'L. ARB. 109 (1994).

69 Wang Shengchang, Arbitration jurisdiction Determination System with Chinese Characteristics, 5 Arbitration AND LAW, 11 (2003).

70 Feng, supra note 56. 
which arbitration commissions make decisions on arbitration jurisdiction can effectively avoid conflicting decisions made by individual arbitrators on similar issues, and unnecessary delay of procedures. 71 For instance, according to the Arbitration Rules of the China International Economic and Trade Arbitration Commission, double review shall not be imposed on jurisdictional matter in one and the same case, and disputes over jurisdiction are considered by arbitration commissions as a matter of emergency. This mechanism is expected to reduce expenses and to speed up arbitral procedures effectively. ${ }^{72}$

The present author believes that, in view of the arbitration legislation framework as embodied in the Chinese Arbitration Law and the current functioning of Chinese commercial arbitration, objective reasons for supporting the unique Chinese "competence-competence" system can easily be found. For instance, China has attached more importance to the role of arbitration institutions for quite a long time already, whereas functions of arbitral tribunals or sole arbitrators are neglected. As a result, Chinese arbitration institutions function differently from other arbitration institutions. However, one will be improvidence to take the view that nothing needs to be improved with respect to relevant arbitration legislation in China and customary practice without in-depth thinking should be in place. On one hand, the function of arbitration institutions to guide and coordinate the hearing of arbitral tribunals must be emphasized; while on the other hand, negative influences on the impartial and independent hearing of cases by arbitral tribunals or arbitrators resulting from the application of authority by arbitration institutions have be restricted. Undoubtedly, the correct direction for the promotion of international commercial arbitration is to bring Chinese legislation and practice in the field of international commercial arbitration into correspondence with international common practice, and to diminish the function of arbitration institutions with respect to arbitrational jurisdiction strictly in accordance with the original idea of the "competence-competence" theory, so as to entitle arbitral tribunals and arbitrators to determine their own jurisdiction.

71 Wang Shengchang, Arbitration jurisdiction Determination System with Chinese Characteristics, 5 ARBITRATION AND LAW 16 (2003).

72 See Wang Sheng Chang, A Comparative Survey of the Rule of the Arbitration Institute of the Stockholm Chamber of Commerce and the Arbitration Rule of the China International Economic and Trade Arbitration Commission, 4 J. INTL. ARB. 106 (1992). 


\section{Can the Authority of Chinese Courts to Decide on Arbitrational Jurisdiction Challenge the Jurisdictional Award Made by a Foreign Arbitral Institution? And Does the Invalidity of an Arbitration Agreement Constitute the Only Reason to Challenge the Arbitral Jurisdiction?}

If within the context of international commercial transactions, a Chinese party and a foreign party enter into an arbitration agreement entitling them to submit disputes to a judicial or arbitral forum in a foreign country; notably disputes arising over the validity of that arbitral agreement, and one party submits such a dispute to a foreign arbitral institution while the other party submits it to a Chinese court, does the judgment passed by the Chinese court override the award rendered by the foreign arbitral institution? Another relevant issue is the applicable law relied on by courts to decide on the validity of arbitration agreements, in particular, when parties fail to make a choice on the law applicable to the arbitration agreement. Which law, lex fori or the law of the place of arbitration, shall be applied by courts to decide the validity of an arbitration agreement? Some cases have been decided by Chinese courts in the past, ruling that the competence of Chinese courts to determine the validity of arbitration agreements overrides that of foreign arbitration institutions; as in the case of the "Revpower Case" decided by the Shanghai Intermediate People's Court in March, 1996.73 In the Revpower case, the foreign party entered into a compensation trade agreement with a PRC entity in 1988. When the Chinese party allegedly insisted that the price be increased in violation of the contract and could not obtain a performance guarantee as required under the contract, the foreign party announced in December 1989 that the Chinese party was in breach and terminated the contract. After 18 months of negotiations, the foreign party initiated arbitration in Stockholm in July 1992. The Chinese party raised a jurisdictional objection, which the tribunal rejected. The Chinese party filed a counterclaim against the foreign party in Shanghai in March 1993. The foreign party objected to the suit because arbitration had already been filed abroad. The court did not decide the issue for two years. Meanwhile, the Chinese party withdrew from the arbitration proceeding abroad, having asserted the right to do so at its initial appearance. Accordingly, the Stockholm tribunal issued a default award in favor of the foreign party in the amount of \$ 4.5 million plus interest and fees in July 1993. The foreign party sought enforcement in December 1993 at the Shanghai Intermediate Court. The court refused to accept the

73 Though at that time the Arbitration Law was not in effect and Article 20 thereof could not be relied on as a legal basis for judgment, Article 257 of the Chinese Civil Procedure Law does provide that the People's Courts shall not accept and hear cases which have been contracted by parties to submit to arbitration. 
filing fees on the ground that there was already an action pending. The foreign party sought assistance from the PRC Ambassador to the U.S., U.S. Embassy officials in Beijing, members of the U.S. Congress and Ministry of Foreign Trade \& Economic Cooperation (MOFTEC) officials - all to no avail. Nevertheless, the foreign party continued to press its case. Finally, under pressure from the Supreme Court, the Shanghai Intermediate Court accepted the case in February 1999. In March 1999, the court recognized the award. However, by that time, the Chinese party had apparently transferred its assets to other companies. ${ }^{74}$ According to one authoritative PRC commentator, the court made at least three mistakes. First, it wrongfully accepted the Chinese party's application for commencing a legal proceeding in relation to the same dispute that had been submitted to arbitration. Second, it erroneously applied PRC law to interpret the validity of the arbitration agreement. Third, it delayed the enforcement proceedings. 75 It is obviously that in the above case, the Chinese court took the view that the competence of Chinese courts to determine the validity of arbitration agreements overrides that of foreign arbitration institutions. Moreover, despite of the foreign involvements in this case, being lack of the agreement as regards the applicable law of the validity of the arbitration agreement, the Chinese court wrongfully apply Chinese law(instead of lex fori or the law of the place of arbitration,) to determine the (in)validity of the arbitration agreement. The present author considers that Article 20 of the Chinese Arbitration Law, according to which the competence of courts to determine the validity of arbitration agreement overrides that of arbitration institutions, only applies to arbitration conducted or to be conducted in China. The explanation for this view is that Chinese courts have no right to exercise judicial supervision over foreign arbitration institutions. Moreover, if parties fail to choose the law applicable to the arbitration agreement, unless the arbitration agreement has designated Chinese law as the law applicable, the law of the place where the award is made will be the law applicable according to Article 5(1) of New York Convention (1958). Therefore, under such circumstances, judgments made by Chinese courts cannot be deemed to have superior effect.76 Indeed, if the validity of an arbitration agreement is confirmed by a foreign arbitration institution, a converse judgment made by a Chinese court cannot

74 Alberto Mora, The Revpower Dispute: China's Breach of the New York Convention? in CHRIS HunTER (ed.), Dispute Resolution in the PRC: A Practical Guide to Litigation and Arbitration in China 151-158 (World Pubn Service 1995).

75 Wang Shengchang, Enforcement of Foreign Arbitral Awards in the People's Republic of China, in ALBERT JAN

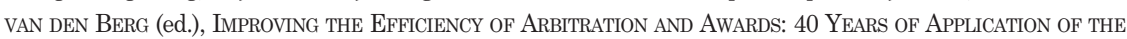
New York Convention 461, 499 (ICCA Congress SERIEs No. 9 1999).

76 Zhao Xiuwen, The Principle Applied in Arbitration jurisdiction---from the Angle of "Revpower Case," 6 Arbitration and LaW Communication (1996). See also Randall Peerenboom, Seek Truth From Facts: An Empirical Study of Enforcement of Arbitral Awards in the PRC, 49 AM. J. ComP. L. 249 (2001). 
actually prevent the foreign arbitration institution from continuing its arbitral proceedings by virtue of its affirmative decision on the validity of arbitration agreement. 77

In addition to the above-mentioned issues arising under Chinese arbitration legislation, another problem is that Article 20 of the Arbitration Law only deals with jurisdictional challenges by reference to the alleged (in)validity of arbitration agreement. Moreover, Article 16 does not stipulate other elements such as the competence of arbitration institution as valid conditions for an arbitration agreement. However, the issue of arbitrational jurisdiction is not solely concerned with the validity of arbitration agreements. It appears that the Arbitration Law provides no guidelines on how to deal with a challenge which is not related to the arbitration agreement itself, but for instance to the arbitrability of an issue (the question of whether a specific issue can be the subject of arbitral review) or to the competence of the arbitration institution in question.

\section{E. Suggestions}

The present author believes that Chinese legislative, judiciary and arbitration circles should first develop a correct attitude towards arbitration issues such as the function and value of arbitration, judicial supervision, and support of courts towards arbitration. Appropriate understanding and recognition of the positive assets of arbitration would be in accordance with the increasing worldwide tendency towards acceptance of international commercial arbitration as a valuable modern dispute settlement mechanism. This will provide a proper basis, and as well, constitute a prerequisite for China to effectively and correctly solve the problems currently arising from the somewhat distorted relationship between courts and arbitral institutions. Within the framework of a genuine effort to eradicate unnecessary competence conflicts between courts and the arbitration institutions, it is suggested here that the following points of departure and principles should be taken into account by Chinese legislative and judicial bodies:

First, judicial supervision over arbitration shall become more moderate so as to demonstrate recognition of the internationally accepted value and merits of arbitration. For a healthy development of arbitration, courts' judicial supervision should not be cancelled completely; nevertheless, courts shall no longer impose any excessive interference with or control over arbitration. A healthy development of arbitration requires a legally sound moderate judicial supervision. ${ }^{78}$ In order to realize moderate

\footnotetext{
Chen Zhidong, supra note 60, at 144 .

78 Zhao, supra note 13 , at 15.
} 
judicial supervision, the following suggestions may be useful: Acknowledging the finality of arbitral awards; while recognizing, in particular, that substantive issues are to be exempted from the scope of judicial review, and that the extent of review is to be strictly narrowed to procedural issues; and ensuring that the role of courts in the arbitration process shall be directed towards support and assistance, instead of obstruction, and that applications filed by parties or arbitral tribunals shall serve both as a precondition for court interference with arbitration and as a criterion for determining the scope of such interference.

Second, the official approach adopted towards arbitration should become more conducive to promoting the speedy and impartial resolution of international commercial disputes.

Arbitration and litigation, though their procedural nature is different, share a common purpose as legal methods aimed at promoting a speedy and impartial resolution of disputes. Therefore, in order to encourage the settling of disputes reasonably and strictly in accordance with the law, and to develop an internationally respected commercial disputes settlement mechanism, this point of departure shall be consistently borne in mind by confirming the legal validity of properly concluded arbitration agreements; thereby resolving a major potential source of conflict over the jurisdiction of courts and arbitral institutions.

Prior to the modification and improvement of relevant Chinese arbitration laws, with a view to promote an arbitration-friendly exercise of courts' judicial supervision over arbitration and understanding and acceptance of the principle of "competencecompetence" in line with internationally accepted views, legislation should be enacted and/or jurisprudence be issued to ensure that Article 20 of the Chinese Arbitration Law shall henceforth be interpreted in the following way: In the first place, arbitration institutions' "right to determine their own jurisdiction" shall be respected in legal practice. In the event that parties have a dispute over the validity of an arbitration agreement and submit this dispute to an arbitral institution instead of a court for decision, the arbitral institution is entitled to definitely determine the validity of arbitration agreement; and to pass judgment on its own jurisdiction. If the arbitral institution confirms its jurisdiction, such confirmation is unconditionally valid until the end of the arbitration proceedings in question. During the time of the proceedings, parties shall not submit any application to a court to challenge or confirm the validity of the arbitration agreement. Secondly, the judicial supervision of courts over arbitration shall be moderate. In the event that the parties have a dispute over the validity of an arbitration agreement, and one party submits an application to a People's Court to confirm or deny the validity of that agreement prior to submission of an application by 
the other party to an arbitral institution, the decision on arbitral jurisdiction shall be made by the People's Court, and such decision shall be final. The People's Court is entitled to review challenges raised by parties against a jurisdiction decision made by an arbitral institution when the revocation or recognition, or enforcement of, an arbitral award is in dispute. In addition, if the arbitral organ rejects its own jurisdiction, parties may refer challenges to a People's Court immediately or apply to the People's Court to review the validity of the arbitration agreement in question and the People's Court shall decide on this issue.

The present legal framework on the establishment of arbitration jurisdiction as embodied in Article 20 of the Chinese Arbitration Law is far from comprehensive and perfect, and some of the provisions still fail to keep up with current international commercial arbitration standards. Relevant laws should be modified accordingly, mainly on the following aspects: The principle of competence de la competence, which has become universally adopted and recognized in most countries, shall be adopted and effectively implemented also in the PRC, in a way which promotes jurisdictional competence of arbitral institutions. This will contribute to a broader recognition of the positive assets of the jurisdictional competence of arbitral institutions. It is proposed that the Arbitration Law shall clearly provide that courts shall not seize and hear cases concerning the (in)validity of arbitration agreements before the initiation of arbitral proceedings, unless either party has submitted an application to a court prior to or simultaneous with the submission of an application to an arbitral institution by the other party. Court interference with arbitration shall not precede arbitral proceedings, and the impact of judicial review and supervision on arbitral proceedings shall be reduced to a legally required minimum.

\section{Conclusion}

Arbitration agreements, the cornerstone of the international commercial arbitration system, form the hinge of arbitration litigants, arbitration institutions (arbitral tribunals) and courts with the key function to establish and promote commercial arbitration jurisdiction. A valid arbitration agreement not only establishes arbitral tribunals' arbitration jurisdiction, but also restricts litigants' rights to litigation and limits courts' judicial jurisdiction. The principle of "competence-competence" is based on the autonomy of the arbitration clause. Acceptance of this doctrine is required, particularly with respect to international arbitration in order to prevent recalcitrant parties from 
evading their arbitral obligations by merely asserting that the contract, which contains the arbitration clause, was invalid; Civil law Jurisdictions entitle arbitral tribunals an extensive "competence-competence" authority. Thus, the principle of "competencecompetence" in favor of arbitral institutions is developed in line with the global trend towards a "pro-arbitration" attitude, the essence of which is to allow disputing parties to solve their disputes within the scope of an arbitration system by relying on arbitration agreement clauses.79 Thus, opting for arbitration instead of litigation is in line with actual commercial dispute settlement trends worldwide. However, in light of current regulation allowing judicial supervision of courts over arbitration, courts are entitled to finally determine the scope of arbitral jurisdiction. The principle of "competencecompetence" in favor of arbitral institutions and the possibility of court determinism in China entail some irreconcilable elements. Though arbitral institutions' right to decide their own jurisdictional scope is finally subject to the judicial authority, courts, when exercising such authority, should bear in mind the international tendency towards a notion of "pro-arbitration" attitude and reduce the impact of their judicial supervision over arbitral proceedings.

New legislation and practice, conducive to more effectively implementing the principle of competence de la competence, while more willingly respecting the original ideas behind it, within the Chinese arbitration framework is due. This is called for so as to line up with internationally accepted perceptions of modern international commercial arbitration, and to develop a more modern Chinese commercial arbitration system. Undoubtedly this will ultimately serve China's effort to attract foreign investment and to strengthen its internationally competitive economic position. 